\title{
The Standardization of Halal Tourism Management in West Nusa Tenggara
}

\begin{tabular}{|c|c|}
\hline \multicolumn{2}{|c|}{ Faculty of Law, Universitas Sebelas Maret, Surakarta, Indonesia } \\
\hline Info Artikel & Abstract \\
\hline $\begin{array}{l}\text { Keywords: } \\
\text { Standarization, Halal Tourism, } \\
\text { West Nusa Tenggara }\end{array}$ & $\begin{array}{l}\text { This research aims at explaining the standardization of halal } \\
\text { tourism management in West Nusa Tenggara. The result } \\
\text { shows that the standardization of halal tourism management } \\
\text { through Regional Regulation Number } 2 \text { of } 2016 \text { on Halal } \\
\text { Tourism has not solved the problems of regional tourism } \\
\text { such as good environmental maintenance from the } \\
\text { increasingly damaged biology resource crisis, the } \\
\text { deforestation, the limited water resources, soil erosion, } \\
\text { sedimentation, abrasion on the cost, coral reef damage, } \\
\text { littering } 53 \% \text { or about } 250 \text { ton plastic waste every day. Even, } \\
\text { this regional regulation is in contrary to the higher laws and } \\
\text { religious nuances. }\end{array}$ \\
\hline & Abstrak \\
\hline $\begin{array}{l}\text { Kata kunci: } \\
\text { Standarisasi; Pariwisata Halal; } \\
\text { Nusa Tenggara Barat. }\end{array}$ & $\begin{array}{l}\text { Penelitian ini bertujuan untuk menjelaskan standarisasi } \\
\text { pengelolaan wisata halal di Nusa Tenggara Barat. Hasil } \\
\text { penelitian menunjukkan bahwa standarisasi pengelolaan } \\
\text { pariwisata halal melalui Peraturan Daerah Nomor } 2 \text { Tahun }\end{array}$ \\
\hline $\begin{array}{l}\text { Corresponding Author: } \\
\text { Abdul Kadir Jaelani, E-mail: } \\
\text { jaelaniabdulkadir@staff.uns.ac.id }\end{array}$ & $\begin{array}{l}2016 \text { tentang Pariwisata Halal belum menyelesaikan } \\
\text { permasalahan pariwisata daerah seperti pemeliharaan } \\
\text { lingkungan yang baik dari krisis sumber daya hayati yang } \\
\text { semakin rusak, penggundulan hutan, sumber daya air yang } \\
\text { terbatas, tanah erosi, sedimentasi, abrasi biaya, kerusakan }\end{array}$ \\
\hline $\begin{array}{l}\text { P-ISSN: 1412-6605 } \\
\text { E-ISSN: 2301-6426 }\end{array}$ & $\begin{array}{l}\text { terumbu karang, membuang sampah sembarangan } 53 \% \\
\text { atau sekitar } 250 \text { ton sampah plastik setiap hari. Bahkan } \\
\text { peraturan daerah ini bertentangan dengan peraturan } \\
\text { perundang-undangan yang lebih tinggi dan bernuansa } \\
\text { agama. }\end{array}$ \\
\hline
\end{tabular}

\section{Introduction}

World tourism has increased positively every year. Since 1950, the world tourists have been 25 million tourists with the value of 2 billion dollar, and the increase reached 1.186 million dollar in 2015 with the tourists' activity value of 1.260 billion dollar. It makes the tourism as one of the sectors to improve the 
economy if the countries are able to make use maximally the tourism prospects they have. ${ }^{1}$

Indonesia is one of countries with a lot of tourism potentials. In the 2015-2019 Tourism Development Plan, the Indonesian government divided the tourism development targets into two, namely growth targets and inclusive development targets. The growth target had three main aspects; contribution to Gross Domestic Product (GDP); foreign tourist visits; and domestic tourist visits. ${ }^{2}$ GDP in 2014 was $4.2 \%$ with the target of $8 \%$ in 2019. The number of foreign tourist arrivals in 2014 was 9 million, and was expected to reach 20 million in 2019. While the number of domestic tourist arrivals in 2014 was 250 million, and reached 275 million in 2019. The foreign exchange income in 2014 reached 120 trillion rupiah and an estimated of 240 trillion rupiah in 2019. The inclusive development sector was expected to be able to increase local businesses in the tourism industry and be able to increase certified local workforce. ${ }^{3}$

Indonesian development tourism has a positive trend. In 2015 this sector was able to contribute to GDP, foreign exchange and employment. National GDP in 2015 reached 10\% with the highest nominal in ASEAN. The growth of GDP national tourism GDP was $4.8 \%$ with an upward trend of $6.9 \%$. It was quite high compared to the agriculture, manufacturing, automotive and mining sectors. Foreign exchange tourism had a value of 1 million dollars in 2015 with a GDP reaching 1.7 million dollars. This sector also provided a fairly good contribution in opening up employment opportunities. This sector was able to contribute up to 9.8 million jobs. ${ }^{4}$

In the international globe, the world tourism has various development trends, one of which is a halal tourism. It is a tourism segment by providing basic necessities needed by Muslim tourists in accordance with Islamic law. However, halal tourism facilities can also be enjoyed by non-Moslem tourists since the core of the facilities only refers to food and beverage with halal labels, halal restaurants, and sharia hotels. In Indonesia, halal certificates can be obtained

${ }^{1}$ David Weaver, Brent D. Moyle, and Char lee McLennan, 'A Core/Periphery Perspective on Mega-Event Sustainability: Dystopic and Utopic Scenarios', Tourism Management, 86.January (2021), $104340<$ https:// doi.org/10.1016/j.tourman.2021.104340>.

2 Enrique Bigne, Juan Luis Nicolau, and Edu William, 'Advance Booking across Channels: The $\begin{array}{llllll}\text { Effects on Dynamic Pricing', Tourism Management, } 86 & \text { (2021), } 104341\end{array}$ $<$ https://doi.org/10.1016/j.tourman.2021.104341>.

${ }^{3}$ Sang Gon (Edward) Lim and Chihyung Michael Ok, 'A Meta-Analytic Review of Antecedents of Hospitality and Tourism Firms' Performance: A Cross-Cultural Comparison', Tourism Management, 86.March (2021), 104325 <https://doi.org/10.1016/j.tourman.2021.104325>.

${ }^{4}$ Ludovica Moi and Francesca Cabiddu, 'An Agile Marketing Capability Maturity Framework', Tourism Management, 86.May (2021), 104347 <https:/ / doi.org/10.1016/j.tourman.2021.104347>. 
from the National Sharia Council-Indonesian Ulema Council. ${ }^{5}$ This trend is developing not only in Muslim-majority countries, but also in countries with Muslim-minority populations, such as Australia by providing Muslim Travel Guide travel, as well as the UK through Serendipity Travel by providing facilities to facilitate worship for Muslim tourists (such as prayer timetable, prayer equipment, and others) and so do Hong Kong, Thailand, and South Korea offer halal tourism facilities. ${ }^{6}$

Besides, an economic sector, the increasing number of Muslim populations is also as a factor of halal tourism development. In 2010, the world's Muslim population ages between 14-29 years reaching 457,950 million people and in 2020 it estimates reaching 501,070 million people. A high population with a productive age range is expected to increase tourist travel, so the halal tourism segment will become one of the country's potential foreign exchange incomes. ${ }^{7}$

According to Burhan Bungin, the data increase is caused by a brand seen by tourists. Burhan Bungin further argues that the brand will stimulate the purchases and differences of tourist visits in the two Provinces because the brands in these two Provinces are constructed differently so it makes different stimulations to the tourism visitors. Undoubtedly, the yearly increase of tourist arrivals influences on the increase of the regional income of the tourism sector, especially from hotel taxes, restaurant taxes, entertainment taxes, recreation, sports and abattoirs levies. The increase certainly had a positive impact on foreign exchange incomes and the regional income of the West Nusa Tenggara Province. ${ }^{8}$

Referring to these developments, it is very important for Indonesia to build a halal tourism standardization model. One of very good for the halal tourism development is West Nusa Tenggara with a vision of "Faithful, Culture, Competitive and Prosperous". The word 'Faithfull' at the beginning of this vision is the people image of West Nusa Tenggara devoting their religion and applying their religion principals in their daily lives. With the majority of West Nusa Tenggara are Muslim, this area is considering as the appropriate halal tourism

${ }^{5}$ Asli D.A. Tasci and Maksim Godovykh, 'An Empirical Modeling of Transformation Process through Trip Experiences', Tourism Management, 86.April (2021), 104332 <https://doi.org/10.1016/j.tourman.2021.104332>.

${ }^{6}$ Adiyukh Berbekova, Muzaffer Uysal, and A. George Assaf, 'A Thematic Analysis of Crisis Management in Tourism: A Theoretical Perspective', Tourism Management, 86. March (2021), $104342<$ https://doi.org/10.1016/j.tourman.2021.104342>.

${ }^{7}$ Haisheng Hu, Yang Yang, and Jin Zhang, 'Avoiding Panic during Pandemics: COVID-19 and Tourism-Related Businesses', Tourism Management, 86.March (2021), 104316 <https://doi.org/10.1016/j.tourman.2021.104316>.

${ }^{8}$ Kanghwa Choi, Hee Jay Kang, and Changhee Kim, 'Evaluating the Efficiency of Korean Festival Tourism and Its Determinants on Efficiency Change: Parametric and Non-Parametric $\begin{array}{lllll}\text { Approaches', } & \text { Tourism } & \text { Management, } & \text { 86.May } & \text { (2021), }\end{array}$ <https://doi.org/10.1016/j.tourman.2021.104348>. 
development. As a result, West Nusa Tenggara received an award from the World Halal Travel Summit held in Abu Dhabi for two consecutive years with the nomination: the world's best halal tourism destination, the world's best halal honeymoon tourism, and the best halal travel website. For this achievement, West Nusa Tenggara has successfully presented itself as a halal tourism model. However, this achievement is not followed by the concept of halal tourism management standards in West Nusa Tenggara. ${ }^{9}$

\section{Methods}

This was a combination study of normative and empirical legal research. A normative legal research focuses on a library research in which the data is collected from various literatures, both libraries and other places while the data of an empirical legal research is obtained from field researches; observations and in depth interview with respondents and informants who are competent and in relation with the topic studied. This study was categorized as a descriptive research aiming at collecting and classifying the cases found by the researchers to strive for perfection on the basis of building research problems. ${ }^{10}$

This research was used primary and secondary sources. The primary data was empirical facts obtained directly from the respondents. The secondary data was obtained directly from the research location that was by direct-interviewing with respondents and informants who are competent and in relation with the topic studied. The research location was in West Nusa Tenggara province. In this research, the researchers also decided a number of respondents and informants. The respondents were chosen based on specific considerations and criteria with enough background knowledge of respondent population. ${ }^{11}$ The respondents were chosen based on the specific criteria which had a close relation with the case being studied and in accordance with the research objectives. ${ }^{12}$ Those criteria included performance, position, interaction, respondent roles in tourism management, respondents living in West Nusa Tenggara or tourists once coming to West Nusa Tenggara. The secondary data was legal data obtained from a library research consisting of primary legal source, secondary legal source, and

${ }^{9}$ Fengyu Li and others, 'How and When Servant Leadership Promotes Service Innovation: A Moderated Mediation Model', Tourism Management, 86.July 2020 (2021), 104358 $<$ https://doi.org/10.1016/j.tourman.2021.104358>.

${ }^{10}$ Wenting Feng and others, 'How Being Envied Shapes Tourists' Relationships with Luxury Brands: A Dual-Mediation Model', Tourism Management, 86.March (2021), 104344 $<$ https://doi.org/10.1016/j.tourman.2021.104344>.

11 Ding $\mathrm{Xu}$ and others, 'Reaching Audiences through Travel Vlogs: The Perspective of $\begin{array}{llll}\text { Involvement', Tourism } \quad \text { Management, } & \text { 86.March } & \text { (2021), }\end{array}$ <https://doi.org/10.1016/j.tourman.2021.104326>.

12 Xiaoyi Wu, Jie Wang, and Qian Ling, 'Managing Internal Service Quality in Hotels: Determinants and Implications', Tourism Management, 86.March (2021), 104329 <https://doi.org/10.1016/j.tourman.2021.104329>. 
non-legal source. The secondary data was obtained from related documentation and literature study. Legal data to obtain the secondary source consisted of the primary legal source, the secondary legal source, and the tertiary legal source. ${ }^{13}$

\section{Results and Discussion}

\section{The Concept of Halal Tourism}

The terminology of halal tourism emerges at the beginning as the tourists' activity to develop their sense motivation and religious value by visiting worship places, cemetery, or historical religious places in accordance with their belief. At the beginning, this tourism is called as a religious tourism. Then, this religious tourism has developed since the tourism segment is not only for a specific religion. The universal value and the benefits for the society such as an education and local wisdom value are also not left behind. In addition, the public perception of a religious tourism is a tourist activity to visit mosques or cemeteries. In fact, the religious tourism itself includes cultural, natural, and artificial tourisms with the Islamic values and principles. ${ }^{14}$

There are other terms of halal tourism used by a number of countries such as, Halal Travel, Halal lifestyle, Islamic Tourism, Halal Friendly Tourism Destination, or Muslim-Friendly Travel Destination. Another term of halal tourism is also mentioned by Abdul Kadir Jaelani as Islamic Tourism in which Muslim tourists travel to a place to improve their creed and practice their Islamic principles. For the detail, Table 1 describes the differences of halal, religious, and conventional tourisms:

\section{Table 1}

The Differences of Halal, Religious, and Conventional Tourisms

\begin{tabular}{|c|c|c|c|c|}
\hline No. & Element & Conventional & Religious & Halal \\
\hline 1. & Object & $\begin{array}{l}\text { Nature, cultural } \\
\text { heritage, culinary }\end{array}$ & $\begin{array}{l}\text { Historical heritage, } \\
\text { worship place }\end{array}$ & all \\
\hline 2. & Goal & Entertainment & Spiritual motivation & $\begin{array}{l}\text { Religious } \\
\text { motivation with } \\
\text { entertainment }\end{array}$ \\
\hline 3. & Target & $\begin{array}{l}\text { Satisfaction } \text { and } \\
\text { happiness with the } \\
\text { desire dimension as } \\
\text { entertainment }\end{array}$ & $\begin{array}{l}\text { Spiritual aspect to } \\
\text { regain equanimity }\end{array}$ & $\begin{array}{l}\text { Self-desire } r \\
\text { happiness as well as to } \\
\begin{array}{l}\text { gain } \\
\text { awareness }\end{array}\end{array}$ \\
\hline
\end{tabular}

13 Tianyu Ying and others, "II Have to Watch My Back": Exploring Chinese Hotel Guests' Generalized Distrust and Coping Behavior', Tourism Management, 86.July 2020 (2021) <https:/ / doi.org/10.1016/j.tourman.2021.104355>.

14 Wenjie Cai, Maria Gebbels, and Wan Hafiz Wan-Zainal-Shukri, 'Performing Authenticity: Independent Chinese Travellers' Tourism Dining Experiences in Europe', Tourism Management, 86.July 2020 (2021), 104339 <https:/ / doi.org/10.1016/j.tourman.2021.104339>. 


\begin{tabular}{|c|c|c|c|c|}
\hline 4. & Tourism Guide & $\begin{array}{l}\text { Understand and } \\
\text { master tourism } \\
\text { objects to attract the } \\
\text { tourists }\end{array}$ & $\begin{array}{l}\text { Know and understand } \\
\text { tourism location history } \\
\text { and objects }\end{array}$ & $\begin{array}{l}\text { Gain the tourist } \\
\text { religious spirit and } \\
\text { explain the benefits } \\
\text { and roles of spiritual } \\
\text { happiness in the } \\
\text { Islamic contexts }\end{array}$ \\
\hline 5. & $\begin{array}{l}\text { Worship } \\
\text { facilities }\end{array}$ & Only equipment & Only equipment & $\begin{array}{l}\text { To be part of tourism } \\
\text { destination, and ritual } \\
\text { worships as an } \\
\text { entertainment } \\
\text { package }\end{array}$ \\
\hline 6. & Culinary & Public & Public & Halal certified \\
\hline 7. & $\begin{array}{l}\text { Relation with } \\
\text { the community } \\
\text { surrounding the } \\
\text { tourism } \\
\text { destination }\end{array}$ & $\begin{array}{l}\text { Complementary } \\
\text { and only to get } \\
\text { benefits }\end{array}$ & $\begin{array}{l}\text { Complementary and } \\
\text { only to get benefits }\end{array}$ & $\begin{array}{l}\text { Integrated, interact in } \\
\text { accordance with the } \\
\text { Islamic principles }\end{array}$ \\
\hline 8. & Travelling plan & $\begin{array}{l}\text { The tourists do not pay } \\
\text { attention to the time. }\end{array}$ & $\begin{array}{l}\text { The tourists pay } \\
\text { attention to the time. }\end{array}$ & $\begin{array}{l}\text { The tourists do not } \\
\text { pay attention to the } \\
\text { time. }\end{array}$ \\
\hline
\end{tabular}

Source: Abdul Kadir Jaelani, "Implikasi Berlakunya Implikasi Berlakunya Peraturan Daerah Provinsi Nusa Tenggara Barat Nomor 2 Tahun 2016 Tentang Pariwisata Halal di Kota Mataram dan Kabupaten Lombok Timur" Tesis, Program Pascasarjana Universitas Gadjah Mada, Yogyakarta Tahun 2017

The important thing for Muslim tourists is the personal needs of a Muslim such as swimming pools, sports facilities, tourism spots with mahram and non-mahram boundaries. A number of halal tourism services must: (1) fulfill at least two aspects such as Islamic praying rooms and halal tourism, (2) have toilet facilities with highness water and Ramadan services or facilities, (3) and then be suggested no alcoholic beverages and of course a good recreation service. However, this facility is also for public tourists (not only for Muslim), since this segment universally includes cultural, natural, and traditional tourism. What makes the main character of halal tourism is the packages of the Islamic principles and values enjoyed all tourists from various religious backgrounds by facilitating the basic demand of Muslim tourists such as assessable praying rooms, halal food and beverages, and Muslim tourists' accommodation such as sharia hotels.

\section{Halal Tourism West Nusa Tenggara}

West Nusa Tenggara has Regional Regulation Number 2 of 2016 about halal tourism as a guideline to develop a halal tourism model. This regulation aims to help and provide a pleasant feeling when having a tour. One of the examples is the concept of sharia hotels in which the tourists are able to stay and pray comfortably (especially for Muslim tourists by 
providing praying equipment for the Muslim tourist, the Qur'an, and Qiblah direction in the hotel room). Several sharia hotels that can be visited by the tourists are Svarga Hotel, Grand Madani Hotel, Lombok Plaza Hotel, Grand Legi Hotel, Santika Hotel, Santosa Hotel, Villa Senggigi, Holiday Resort, Lombok Raya Hotel, Sheraton Hotel. ${ }^{15}$

Not only do accommodations provide, but also halal certified products are proven by halal certificates. Those certificates prove that the products have already been halal in accordance with the Islamic laws and values. Those halal certificates are assigned by qualified-halal-certificate institutions namely, the National Sharia Board of the Indonesian Council of Ulama working together with the Institute for Food, Drug, and Cosmetics Study of the Indonesian Council of Ulema. West Nusa Tenggara has halalcertificate services including restaurant-hotel certificates in which there were five registered restaurants-hotels in 2015 and those increased into seventy five restaurants-hotels in 2016. In 2015, restaurants-non hotels consisted of seventy five and increased into one hundred in 2016. West Nusa Tenggara Barat registered twenty halal-certified restaurants in 2015 while in 2016 there were two hundreds halal-certified restaurants. In addition, there were seventy five Small Micro Medium Enterprises with halal certificates and reached into 269 Small Micro Medium Enterprises in $2016 .{ }^{16}$

Other accretive halal entertainments in West Nusa Tenggara are due to the majority of Muslim in this province. Of course, the tourists would be easy to find praying rooms such as mosques/musholla in the shopping centers, tourists' destination, or airports. West Nusa Tenggara is popularly known as "Pulau Seribu Masjid (English: the island of thousand mosques)", spreading in 598 villages with the total of more than 4.500 mosques. As halal destinations, West Nusa Tenggara launches halal tours with a number of Muslim-tourist destination choices, those are: Sade Village, Islamic Centre, Kuno Karang Bayan Mosque, Sesaot, Jurang Malang, Benang Kelambu, Gili Nanggu, Gili Sudak and Gili Kedis. ${ }^{17}$

Three main components of halal tourism development are accommodation, food, and beverages as well as beautiful tourist destinations in order that the tourists feel comfortable and safe. The main

${ }^{15}$ Shan Liu and others, 'To Be Similar or to Be Different? The Effect of Hotel Managers' Rote Response on Subsequent Reviews', Tourism Management, 86.September 2020 (2021), 104346 <https://doi.org/10.1016/j.tourman.2021.104346>.

16 Yang Yang, Lan Jiang, and Zili Zhang, 'Tourists on Shared Bikes: Can Bike-Sharing Boost Attraction Demand?', Tourism Management, 86.March (2021), 104328 <https://doi.org/10.1016/j.tourman.2021.104328>.

${ }^{17}$ Florian Kock, Adiyukh Berbekova, and A. George Assaf, 'Understanding and Managing the Threat of Common Method Bias: Detection, Prevention and Control', Tourism Management, 86.February (2021), $104330<$ https:/ / doi.org/10.1016/j.tourman.2021.104330>. 
halal halal-tour target is Muslim tourists that the population continually keeps increasing. Furthermore, the Muslim characteristics, especially the tourist from Middle East, tend to spend much money every time they have a tour. However, other tourists also can use the services since those halal tours are basically conventional tours with additional Muslim segments. So, those are not only for Muslim tourists, but also for non-Muslim tourists. ${ }^{18}$

\section{The Standardization of Halal Tourism Management in West Nusa Tenggara}

Regional regulation of the province of West Nusa Tenggara Number 2 of 2016 on halal tourism is the implementation of tourism decentralization stated in Article 236 paragraph (3) Law of the Republic of Indonesia Number 23 of 2014 on Local Government and Law of the Republic of Indonesia Number 10 of 2009 on Tourism. The regulation standardizes the halal tourism management to integrate sharia values to tourism activities by providing sharia-standardized facilities and services. The law protection of Muslim tourists who have an obligation in accordance with their religion and also has the need of worship along with doing tourism activities is needed. The regulation aims at giving economic benefits, safety, and comfortable services to the tourists in enjoying the safe, halal tours and also to facilitate the tourists and tourism management. ${ }^{19}$

Furthermore, the National Sharia Board of the Indonesian Council of Ulama, hereinafter referred as DSN-MUI states Fatwa Number 08/DSNMUI/X/2016 on the standardization of Sharia tourism development. This fatwa includes agreements, hotels, tour destination, SPA, sauna, message, travel agencies, or tour guides. However, if it is closely observed, those DSN-MUI fatwas make halal tourism to be an exclusive tour. In fact, halal tourism is not only for Muslim tourists, but also for public tourists without considering any religion, ethnic, race and many others. The main purpose of halal tourism is an extended service or a maximal tourist service. In addition, those fatwas use various term interpretations if there is no boundary explaining. The example is the term "khurafat", this term needs to be explained clearly since several activities are seen as 'khurafat' for specific groups, but not for another group..$^{20}$

${ }^{18}$ Teresa Villacé-Molinero and others, 'Understanding the New Post-COVID-19 Risk Scenario: Outlooks and Challenges for a New Era of Tourism', Tourism Management, 86 (2021) $<$ https://doi.org/10.1016/j.tourman.2021.104324>.

19 Florian Kock, 'What Makes a City Cool? Understanding Destination Coolness and Its Implications for Tourism', Tourism Management, 86.March (2021), 104317 <https://doi.org/10.1016/j.tourman.2021.104317>.

${ }^{20}$ Noppadol Phaosathianphan and Adisorn Leelasantitham, 'An Intelligent Travel Technology Assessment Model for Destination Impacts of Tourist Adoption', Tourism Management Perspectives, 40.August (2021), 100882 <https:// doi.org/10.1016/j.tmp.2021.100882>. 
Those implemented standardization are the opposite with the main reason of foreign tourists who travel to West Nusa Tenggara. Firstly, 40\% of foreign tourists are having a recreation with the family and relatives and escaping from their daily routines. Their main reason is beaches and sun. Secondly, the tourists visiting relatives, family, and friends reach 36\%. Thirdly, the tourists visiting mountains, lakes, scenery, water-fall, and others reach $26 \%$. Fourthly, $22 \%$ tourists travel as a cultural motive to find spiritual experiences, arts, culinary, and shows. This motive is done since the tourists want to try to be a farmer and/or fisherman by paying as stated in the agreement. Those four motives are supported by the data of majority foreign tourists visiting West Nusa Tenggara: ${ }^{21}$

Table 2

Top Ten Tourists Origin to NTB in 2019

\begin{tabular}{|l|l|l|}
\hline No & Country of Origin & Total of Visits \\
\hline 1. & Australia & 256.744 \\
\hline 2. & German & 110.154 \\
\hline 3. & Netherland & 104.714 \\
\hline 4. & British & 100.522 \\
\hline 5. & Malaysia & 95.103 \\
\hline 6. & Italia & 79.525 \\
\hline 7. & France & 79.521 \\
\hline 8. & USA & 54.778 \\
\hline 9. & Swiss & 37.955 \\
\hline 10. & Canada & 34.231 \\
\hline 11. & Other Countries & 10.204 \\
\hline
\end{tabular}

Source: Department of Culture and Touriam in West Nusa Tenggara Province 2019.

The data showed that the tourist motive traveling to West Nusa Tenggara was not influenced by the standardization of halal tourism. Yet, West Nusa Tenggara tourism would be a tourism trend in the future following the complex need of the life and the high demand of working offices especially in Europe. The same motive also had by tourism groups in America, ASEAN, Asia Pacific and Australia. This kind of tourism

${ }^{21}$ Runhong Hu and others, 'Applying Augmented Reality (AR) Technologi[1] R. Hu, C. Wang, T. Zhang, T. Nguyen, V. Shapoval, and L. Zhai, “Applying Augmented Reality (AR) Technologies in Theatrical Performances in Theme Parks: A Transcendent Experience Perspective," Tour. Manag. Pers', Tourism Management Perspectives, 40.September (2021), 100889 <https:// doi.org/10.1016/j.tmp.2021.100889>. 
motive was in line with the tourism products in Lombok such as natural beaches and mountains.

\section{The Problems of the Standardization of Halal Tourism Management in} West Nusa Tenggara

The standardization of halal tourism in West Nusa Tenggara was so exclusive since it was full of religious nuance in Regional Regulation. In fact, the concept of tourism decentralization did not have the slightest urgency to make religion as part of the public. The decentralization focused more on regional implementation aspect expected to empower and bring services closer to the community. Generally, the goal of decentralization was more focused on the regional human resources development in order to be independent and be the government parasite. Then, if the argumentations of regional regulations on religion nuance emerged to accommodate the majority believers, Satjipto Raharjo stated that the understanding of regional regulation was the expression of literal religion interpreting the religion literally or text booked oriented..$^{22}$

The exclusive nuance of the standardization of halal tourism management can be seen in several provisions. Firstly, halal tourism means any tour activity which tourism destination and industry provide product, services, and tourism management that meet sharia standards. According to Ali Sodiqin, sharia meant anything based on the Qur' an and Hadith. It means that halal tourism is anything that met Islamic sharia. On the other hand, haram is anything strictly forbidden by Allah to be done in which someone who breaks is threatened by torture by Allah in the hereafter. In general, the meaning of halal is a case or act that is permitted, permitted, or justified by Islamic law, while haram is a case or action that must or is not permitted by Islamic law.

Secondly, the provisions of the goal of halal tourism standardization give safety and convenience to the tourists in order to enjoy the tour safely, halal, and also get facilities for the tourist and tourism stakeholders. These provisions explain article 1 (1) regulation number 33 of 2014 on Halal Product Guaranty stating that a product is a thing and/or a service referring to food, beverages, medicine, cosmetic, chemical product, biology product, genetic engineering product, and items used by the committee. Halal product is a product that meet Islamic sharia.

Third, the scope of the regulation of halal tourism covers destinations, marketing and promotion, industry, institutional, guidance and supervision and financing. The article also requires the conventional

${ }^{22}$ Jong Hyeong Kim, Hyewon Youn, and Ian Phau, 'A Triple Whammy Effect of Employees' Gender, Job Type, and Service Outcomes on Consumer Behavior', Tourism Management Perspectives, 40.September (2021), 100878 <https:/ / doi.org/10.1016/j.tmp.2021.100878>. 
tourism industry to provide Qibla direction in hotel rooms, information on nearby mosques, places of worship for Muslim tourists and employees, information on halal / non-halal products, ablution places separate from men and women, supporting facilities to pray and separate places between men and women and make it easy to purify. The halal tourism industry is tourism businesses that sell tourism services and products which are based on sharia principles as stipulated by DSN-MUI.

These provisions equate with the experience characteristics product and trust (credence characteristics). Whereas destinations, marketing, promotions, industry, institutions are something that can be evaluated, tested, validated and detected accurately and efficiently by the tourists before visiting these destinations. Testing of destinations, marketing, promotions, industry, and institutions can be done individually and manually by the tourists using the senses. For this reason, it is called search characteristics, because consumers can automatically find and test products accurately and efficiently independently and do not need halal certification.

Certification and labeling function of course to ensure that the products traded do not cause information asymmetries and do not mislead the consumers. Likewise, halal certification and labeling on products is a communication tool to provide information and tools to track the halal products for consumers, and serves to ensure that the products traded do not mislead consumers. More fundamentally, that certification and labeling on products serve to change consumers' views of products from experience characteristics to search characteristics, and from credence characteristics to search characteristics. So consumers can choose products with their preferences, based on honest and credible information, which in turn will create fair mading.

\section{Conclusion}

Based on the results of the discussion above, it can be concluded that, the standardization of halal tourism management in West Nusa Tenggara is very exclusive and based on the provisions of the teachings of Islam, whereas the motive of people to travel to West Nusa Tenggara is due to the beautiful natural beaches and mountains. The standardization applied exclusively is contrary to the percentage of the main motives of foreign tourists traveling to West Nusa Tenggara, which is $40 \%$ of foreign tourists aim to do recreation with family and relatives, and escape from daily routine. Their main destinations are the beach and the sun, $36 \%$ visiting relatives, family and friends, $26 \%$ of tourists visiting nature such as mountains, lakes, landscapes, waterfalls and $22 \%$ seeking spiritual experiences, art, culinary and performances. Second, the problem of standardization of halal tourism management in West Nusa Tenggara lies in the 
understanding of halal tourism, destinations, and the scope of halal tourism, labeling and certification.

\section{Refrences}

Berbekova, Adiyukh, Muzaffer Uysal, and A. George Assaf, 'A Thematic Analysis of Crisis Management in Tourism: A Theoretical Perspective', Tourism Management, 86.March (2021), 104342 <https://doi.org/10.1016/j.tourman.2021.104342>

Bigne, Enrique, Juan Luis Nicolau, and Edu William, 'Advance Booking across Channels: The Effects on Dynamic Pricing', Tourism Management, 86 (2021), 104341 <https:// doi.org/10.1016/j.tourman.2021.104341>

Cai, Wenjie, Maria Gebbels, and Wan Hafiz Wan-Zainal-Shukri, 'Performing Authenticity: Independent Chinese Travellers' Tourism Dining Experiences in Europe', Tourism Management, 86.July 2020 (2021), 104339 <https://doi.org/10.1016/j.tourman.2021.104339>

Choi, Kanghwa, Hee Jay Kang, and Changhee Kim, 'Evaluating the Efficiency of Korean Festival Tourism and Its Determinants on Efficiency Change: Parametric and Non-Parametric Approaches', Tourism Management, 86. May (2021), 104348 <https://doi.org/10.1016/j.tourman.2021.104348>

Feng, Wenting, Irina Y. Yu, Morgan X. Yang, and Mengjie Yi, 'How Being Envied Shapes Tourists' Relationships with Luxury Brands: A Dual-Mediation Model', Tourism Management, 86.March (2021), 104344 <https:/ / doi.org/10.1016/j.tourman.2021.104344>

$\mathrm{Hu}$, Haisheng, Yang Yang, and Jin Zhang, 'Avoiding Panic during Pandemics: COVID-19 and Tourism-Related Businesses', Tourism Management, 86.March (2021), 104316 <https:/ / doi.org/10.1016/j.tourman.2021.104316>

$\mathrm{Hu}$, Runhong, Chaohui Wang, Tingting Zhang, Thixuan Nguyen, Valeriya Shapoval, and Lingchen Zhai, 'Applying Augmented Reality (AR) Technologi[1] R. Hu, C. Wang, T. Zhang, T. Nguyen, V. Shapoval, and L. Zhai, "Applying Augmented Reality (AR) Technologies in Theatrical Performances in Theme Parks: A Transcendent Experience Perspective," Tour. Manag. Pers', Tourism Management Perspectives, 40.September (2021), 100889 <https:/ / doi.org/10.1016/j.tmp.2021.100889>

Kim, Jong Hyeong, Hyewon Youn, and Ian Phau, 'A Triple Whammy Effect of Employees' Gender, Job Type, and Service Outcomes on Consumer Behavior', Tourism Management Perspectives, 40.September (2021), 100878 <https:/ / doi.org/10.1016/j.tmp.2021.100878>

Kock, Florian, 'What Makes a City Cool? Understanding Destination Coolness and Its Implications for Tourism', Tourism Management, 86.March (2021), 104317 <https:/ / doi.org/10.1016/j.tourman.2021.104317>

Kock, Florian, Adiyukh Berbekova, and A. George Assaf, 'Understanding and 
Managing the Threat of Common Method Bias: Detection, Prevention and Control', Tourism Management, 86.February (2021), 104330 <https://doi.org/10.1016/j.tourman.2021.104330>

$\mathrm{Li}$, Fengyu, Bing Liu, Weipeng Lin, Xin Wei, and Zikun $\mathrm{Xu}$, 'How and When Servant Leadership Promotes Service Innovation: A Moderated Mediation Model', Tourism Management, 86.July 2020 (2021), 104358 <https:// doi.org/10.1016/j.tourman.2021.104358>

Lim, Sang Gon (Edward), and Chihyung Michael Ok, 'A Meta-Analytic Review of Antecedents of Hospitality and Tourism Firms' Performance: A CrossCultural Comparison', Tourism Management, 86.March (2021), 104325 <https:// doi.org/10.1016/j.tourman.2021.104325>

Liu, Shan, Na Wang, Baojun Gao, and Michael Gallivan, 'To Be Similar or to Be Different? The Effect of Hotel Managers' Rote Response on Subsequent Reviews', Tourism Management, 86.September 2020 (2021), 104346 <https:// doi.org/10.1016/j.tourman.2021.104346>

Moi, Ludovica, and Francesca Cabiddu, 'An Agile Marketing Capability Maturity Framework', Tourism Management, 86.May (2021), 104347 <https://doi.org/10.1016/j.tourman.2021.104347>

Phaosathianphan, Noppadol, and Adisorn Leelasantitham, 'An Intelligent Travel Technology Assessment Model for Destination Impacts of Tourist Adoption', Tourism Management Perspectives, 40.August (2021), 100882 <https://doi.org/10.1016/j.tmp.2021.100882>

Tasci, Asli D.A., and Maksim Godovykh, 'An Empirical Modeling of Transformation Process through Trip Experiences', Tourism Management, 86.April (2021), 104332 <https:/ / doi.org/10.1016/j.tourman.2021.104332>

Villacé-Molinero, Teresa, Juan José Fernández-Muñoz, Alicia Orea-Giner, and Laura Fuentes-Moraleda, 'Understanding the New Post-COVID-19 Risk Scenario: Outlooks and Challenges for a New Era of Tourism', Tourism Management, 86 (2021) <https:/ / doi.org/10.1016/j.tourman.2021.104324>

Weaver, David, Brent D. Moyle, and Char lee McLennan, 'A Core/Periphery Perspective on Mega-Event Sustainability: Dystopic and Utopic Scenarios', $\begin{array}{llll}\text { Tourism Management, } & \text { 86.January (2021), } & 104340\end{array}$ <https:// doi.org/10.1016/j.tourman.2021.104340>

Wu, Xiaoyi, Jie Wang, and Qian Ling, 'Managing Internal Service Quality in Hotels: Determinants and Implications', Tourism Management, 86.March (2021), 104329 <https://doi.org/10.1016/j.tourman.2021.104329>

$\mathrm{Xu}$, Ding, Tingzhen Chen, John Pearce, Zohre Mohammadi, and Philip L. Pearce, 'Reaching Audiences through Travel Vlogs: The Perspective of Involvement', Tourism Management, 86.March (2021), 104326 <https:// doi.org/10.1016/j.tourman.2021.104326>

Yang, Yang, Lan Jiang, and Zili Zhang, 'Tourists on Shared Bikes: Can BikeSharing Boost Attraction Demand?', Tourism Management, 86.March (2021), 
104328 <https:/ / doi.org/10.1016/j.tourman.2021.104328>

Ying, Tianyu, Xiaoyuan Tan, Wei Wei, Yanyan Zheng, Shun Ye, and Maoying Wu, "II Have to Watch My Back": Exploring Chinese Hotel Guests' Generalized Distrust and Coping Behavior', Tourism Management, 86.July 2020 (2021) <https:/ / doi.org/10.1016/j.tourman.2021.104355> 